\title{
Peculiarities of Good Representations of the Fourth forms Single-Lingual and Mixed-Lingual Pupils
}

\section{Особливості уявлення добра одномовних та змішаномовних учнів четвертих класів}

\author{
Oleksii Bedlinskyi \\ Ph.D. in Psychology, \\ Assistant Professor
}

\author{
Олексій Бедлінський \\ кандидат психологічних наук, \\ доцент
}

\section{E-mail: bedlinskyi@i.ua orcid.org/0000-0002-0359-6706}

Tetiana Shcherbak

Ph.D. in Psychology,

Assistant Professor

\section{Тетяна Щербак}

кандидат психологічних наук, доцент

\section{E-mail: shcherbak.tetiana1325@gmail.com orcid.org/0000-0002-7701-9450}

\author{
Sumy State Pedagogical University \\ named after A.S. Makarenko \\ 87, Romenska Str., Sumy, \\ Ukraine, 40002
}

\begin{abstract}
Сумський державний педагогічний університет імені А.С. Макаренка

$\checkmark$ вул. Роменська, 87, м. Суми, Україна, 40002
\end{abstract}

Original manuscript received April 10, 2018

Revised manuscript accepted October 10, 2018

\begin{abstract}
Mixed Russian-Ukrainian dialect in modern junior schoolchildren language, especially bilinguals - is a common phenomenon conditioned by the circumstances of the modern world. The peculiarities of the general representations of mixed-lingual pupils who study at school and communicate outside the lessons in different languages have been revealed in the article; this leads to using a large number of borrowed vocabulary from both languages. In order to study the peculiarities of general representations of Ukrainian,
\end{abstract}


Russian and mixed-lingual pupils, a questionnaire for single-lingual and bilingual pupils of the fourth forms have been conducted. The survey covered 161 students of the fourth forms: 43 pupils who speak at school Ukrainian, and outside of lessons - Russian; 55 pupils - mostly Ukrainian; 66 students mostly Russian. As a result of the study, pupils' differences in general representations and associations of representations with different colors have been detected depending on the language of studying and communication outside the classroom. In the process of mastering the native language, along with the capture of culture and the accumulation of their own experience, associations are formed; even if they are little conscious or generally unconscious they influence the formation of images of representations and their emotional color. Fourth form pupils, whose native language is different from the language of studying, representation of "good» may differ from the views of pupils studying in their native language. Mixed-lingual junior pupils, in comparison with the Ukrainian-speaking and Russian-speaking pupils, in the explanation of the "good", the number of definitions through the opposition "evil» increases, which may threatened with radicalization in the future. Language, among other things, is a system that can fix, store and transmit associations as an inheritance. Different language promotes changing associative links of representations and their emotional color and charging in comparison with the associations of both languages. These changes can be considered as "hereditary-speech mutations», which open wide prospects for psycholinguistic studies of passionarity.

Key words: association, bilingualism, general representations, junior schoolchildren, passionarity, surzhik.

\section{Вступ}

Незважаючи на те, що ще понад сто років тому О.О. Потебня констатував проблему розвитку загальних уявлень у дитячому віці у двомовних дітей, які опановуючи одночасно дві мови, стихійно вживають слова обох мов (Потебня, 1926), вона так і залишилася нерозв'язаною, як на теоретичному, так і на практичному рівні. Сьогодні, як і в XIX столітті знову виявляється, що значній частині наших дітей легше давати визначення\поняття мовою, якою вони навчаються у школі, а пояснювати загальні уявлення мовою, якою вони спілкуються поза уроками.

Звичайно важко дискутувати 3 автором, який написав «заради чистоти вимови, починають навчання іноземної мови мало не 3 пелюшок... так, із дітей 3 чималими здібностями робляться 
напівідіоти...» (Потебня, 1926: 188), щодо шкідливості раннього навчання другій мові, але білінгвізм, як і суржик є об’єктивним фактом нашого часу, а тому необхідні грунтовні дослідження як від'ємних, так і додатніх наслідків, нехтування якими, без перебільшення, може загрожувати національній безпеці.

Отже метою нашої розвідки $є$ дослідження особливостей загальних уявлень добра як «комплексів та псевдопонять» (Выготский, 1982) в україномовних, російськомовних i змішаномовних молодших школярів. Відповідно до мети були поставлені завдання: 1) виявити відмінності уявлень «добра» як «особистісних смислів» в україномовних $\mathrm{i}$ російськомовних молодших школярів; 2) дослідити особливості особистісного смислу загальних уявлень у змішаномовних учнів четвертих класів, які послуговуються надмірною кількістю запозичень 3 другої мови; 3) виявити особливості емоційного забарвлення загальних уявлень у змішаномовних учнів, порівняно з одномовними.

Слід зауважити, що учнів четвертих класів, у яких мова навчання i мова спілкування поза уроками відрізняються, насправді, не можна називати двомовними. Точніше їх назвати змішаномовними - такими, у мові яких велика кількість запозичених слів 3 обох мов. У рамках мети нашої розвідки було висунуто припущення, що у процесі засвоєння української мови формуються загальні уявлення (комплекси, псевдопоняття), які дещо різняться від аналогічних уявлень, що формуються у процесі засвоєння російської мови, оскільки обумовлюються не окремими словами, а кластерами слів: сім'ями слів, стійкими словосполученнями, системою протиставлень тощо. Наприклад, злочинець не може бути добродієм, а «преступник» «благодетелем» - може. За цих умов, у дітей, які у побуті спілкуються мовою, відмінною від мови навчання у школі, вищезгадані уявлення можуть відрізнятися від уявлень як російськомовних, так україномовних дітей.

Сучасні науковці досліджують «добро» переважно, як категорію чи концепт, які більшою чи меншою мірою пов'язані 3 «поняттям добра». Але ще Л.С. Виготський зауважив, що у повсякденному житті ми переважно використовуємо слова-уявлення, а не поняття (Выготский, 1982). Більш продуктивними $є$ дослідження у яких «добро» включається у низку особистісних цінностей, чи мотивацій: доброзичливість, стимулювання, досягнення тощо. Досліджуються 
непрямі та диференційовані асоціації серед вищезгаданих особистих цінностей. На думку Л.В. Романюк, «цінності утворюють континуум пов'язаних мотивацій на більш базовому рівні» (Romanyuk, 2018).

В.П. Зінченко зазначає складність, полізначність i полімодальність збуджуваних словами образів, зауважуючи, що «навіть успішно сформований образ має надмірну кількість ступенів свободи по відношенню до оригіналу, яка повинна бути подолана» (Зинченко, 2010: 259).

Майкл Коуен та інші виявили, що існують обмеження на усвідомлення частини візуальної інформації у процесі ії сприймання. «Анатомічні обмеження на свідому обізнаність можуть бути розповсюдженим явищем, встановлюючи обмеження на усвідомлену обробку в усіх галузях пізнання» (Cohen, 2015: 11). «Візуальна система функціонально організована, що дозволяє ефективно створювати загальні враження дещо незалежно від уявлень про інші об'єкти. Іншими словами, існують окремі нейронні шляхи для представлення лісу та дерев» (Cohen, 2016: 325). Полізначність і полімодальність образів, на нашу думку, долається за допомогою збірних образів (наприклад, трава), які з'являються задовго до усвідомлення видового складу рослинного угрупування.

Важливою для нашої розвідки $є$ гіпотеза лінгвістичної відносності Сепіра-Уорфа. Згідно Уорфу, «мовні навички нашого суспільства зумовлюють вибір інтерпретацій» (Величковский, 2006: 188). Тут слід погодитися 3 думкою Б.М. Величковського, що «сильна версія в дусі Гумбольта та Уорфа, згідно якої мова повністю визначає особливості мислення мало ймовірна» (Величковский, 2006: 188).

Разом із тим у кроскультурних дослідженнях виявляють усе нові факти підтвердження гіпотези лінгвістичної відносності, хоча у більшості цих досліджень висновки, на жаль, робляться на користь теорії «коеволюції генів і культури» див. огляд (Фаликман, 2014), а не на користь лінгвіністичних гіпотез. На нашу думку, гіпотеза лінгвістичної відносності підтверджується до рівня загальних уявлень (комплексів), а далі, чим вищий рівень узагальнень, тим менша пояснювальна здатність гіпотези.

Згідно мовленнєвої гіпотези свідомості (Bedlinskyj, 2017) мова, окрім усього іншого, є системою, яка може фіксувати, зберігати і передавати асоціації у спадок. Тобто, наступні покоління 
отримують у спадок від попередніх поколінь безумовні рефлекси через ДНК, i аналогічно отримують асоціації у процесі вивчення рідної мови. Сім’ї слів, ідіоми, приказки, прислів’я, граматичні та синтаксичні правила тощо можна розглядати як складові цілісного представлення.

Полімодальність і поліобразність збуджуваних словом образів долаються саме 3 допомогою таких уявлень. Ми не можемо передати свої образи іншій людині, але можемо збуджувати образи схожі до наших. Це можливо, або у процесі соціального научіння, яке спостерігається у багатьох звірів i навіть у птахів, або у процесі засвоєння асоціативних зв’язків, які формуються у процесі вивчення рідної мови.

\section{Методи та методики дослідження}

Для розв’язання поставлених задач ми провели анкетування i бесіди зі студентами різних курсів та факультетів Сумського державного педагогічного університету імені А.С. Макаренка, та учнями четвертих класів м. Суми, ряду сільських шкіл Лебединського та Недригайлівського р-нів Сумської обл.

На першому етапі дослідження, з метою уточнення запитань анкети, було проведено опитування студентів. Виявилося, що у відповідях студентів зустрічаються як визначення понять, так i пояснення загальних уявлень, які на нашу думку, залишаються переважно на рівні «комплексів» чи «псевдопонять». Чим конкретніше поняття, тим важче дати визначення.

Складання анкети з низкою запитань, які стосуються моральних категорій, для нашого дослідження виявилося недоцільним, адже коли питання, що стосуються «добра», «справедливості», «любові», знаходяться у одній анкеті - студенти дають визначення одного поняття через інше. Наприклад, добро - це справедливість, чи добро - це любов. Окрім того сучасним студентам нашого університету складно ідентифікувати себе як україномовних чи російськомовних. Частина студентів взагалі назвала рідною мовою - суржик.

Зате було виявлено доцільність пов'язати загальні уявлення 3 уявлюваними кольорами. Тут ми виходили 3 положення, що збуджувані словами образи взаємозв'язані 3 емоційною сферою особистості, а тому асоціюються 3 кольорами. Як писав 
В.П. Зінченко: «...ми цей образ іноді «фарбуємо» у багряні або рожеві тони, уявляємо собі його чуттєві характеристики» (Зинченко, 2010: 288). Окрім того, запитанням «якого кольору добро?», що виявляє зв'язок із візуальними чуттєвими образами, ми хотіли наблизитися до рівня емоційно насичених, але слабо структурованих та мало усвідомлюваних особистісних смислів, які на нашу думку, формуються не лише на основі норм і цінностей суспільства та власного досвіду, а і обумовлюються мовою, у розумінні класичного та оперантного обумовлення.

У дослідженнях студентів було виявлено, що одні уявлення та поняття асоціюються з різними кольорами, а інші переважно 3 одним кольором, наприклад, любов - червоного кольору.

Щоб уникнути виявлених недоліків, і скористатися додатніми результатами, для другого етапу дослідження, ми обрали учнів 4 класів. Анкету скоротили до двох запитань: 1) що таке добро?; 2) якого воно кольору?

Вибираючи для дослідження учнів саме цих класів, ми виходили 3 того, що у цьому віці легше констатувати мову навчання i спілкування у позаурочній діяльності, а на початок підліткового віку можна сподіватися на переважання асоціативних відповідей в учнів 4 класів порівняно 3 предикативними відповідями учнів 1-2 класів з одного боку (Лурия, 1979: 153), та визначеннями понять учнів середньої школи 3 іншого.

Серед досліджуваних учнів були виділені три групи: 1) які спілкуються вдома українською і навчаються в українському класі; 2) які спілкуються вдома російською і навчаються у російському класі; 3) які спілкуються вдома російською і навчаються в українському класі. Перша група - це, переважно, учні сільських шкіл, а друга і третя групи, переважно, учні міських шкіл.

\section{Результати та дискусії}

На першому етапі дослідження було проведено опитування студентів. У результаті опитування було виявлено, що значна частина людей, для яких рідною $є$ російська, дають визначення «добра» через зло: «Добро протилежне злу, добро бореться зі злом, добро коли не роблять зла, тощо». Опозиція «добро зло» частіше пов'язана або 3 нейтральними кольорами, або 3 червоним кольором. 
Peculiarities of Good Representations of the Fourth forms...

На другому етапі дослідження ми провели опитування учнів: четвертих класів сільських шкіл Лебединського та Недригайлівського р-нів Сумської обл., у яких рідною є українська; україномовних та російськомовних класів м. Суми у яких рідною $\epsilon$ російська (див. табл. 1).

Таблиця 1. Визначення «добра» через «зло» україномовними, російськомовними та змішаномовними учнями 4 класів

\begin{tabular}{ccccc}
\hline \multicolumn{1}{c}{$\begin{array}{c}\text { Рідна мова } \\
\text { та мова навчання }\end{array}$} & $\begin{array}{c}\text { Кількість учнів, } \\
\text { які визначили } \\
\text { добро через }\end{array}$ & $\begin{array}{c}\text { Кллолькість учнів, } \\
\text { які у визначенні } \\
\text { добра зло не } \\
\text { згадували }\end{array}$ & $\%$ \\
\hline Український клас, укр. мова вдома & 3 & 5,8 & 49 & 94,2 \\
Російський клас, рос. мова вдома & 1 & 1,5 & 65 & 98,5 \\
Український клас, рос. мова вдома & 6 & 12,8 & 37 & 87,2 \\
\hline
\end{tabular}

Як видно 3 даних поданих у таблиці наша гіпотеза підтвердилася у положенні, що змішаномовні учні $(12,8 \%)$ відрізняються від носіїв української $(5,8 \%)$ і російської $(1,5 \%)$, але не підтвердилася, щодо більш частішого визначення «добра» через опозицію «злу» у російськомовних учнів порівняно 3 україномовними. Троє 352 учнів $(5,8 \%)$ україномовних учнів визначали добро через зло: «Ставитися до інших по доброму, а не по злому. Ні на кого не злися. Не робити зла».

Зважаючи на те, що у відповідях україномовних учнів, які визначали «добро» через «зло», зустрічалися російські слова, ми провели з ними додаткові бесіди. Виявили, що у них вдома говорять двома мовами 3 потужним суржиком. Наприклад, бабуся говорить вдома українською мовою, а тато - російською. Отже, насправді, ïх потрібно віднести до змішаномовних. Аналіз емпіричних даних (див. табл. 1) дає підстави стверджувати, що змішаномовні частіше визначають «добро» через «зло», ніж носії української чи російської мови.

Результати дослідження асоціювання «добра» 3 кольором представлені у табл. 2.

У табл. 2 словом «теплі» ми позначили кольори, які містять жовтий колір (червоний, жовтогарячий, жовтий, золотий). «Холодні» - які містять синій колір (синій, голубий, бірюзовий). «Нейтральні» - кольори, які неможна віднести ні до теплих, ні до 
Особливості уявлення добра одномовних та змішаномовних учнів...

холодних: рожевий, зелений, фіолетовий, сірий, коричневий тощо. Словом «різний» позначили відповіді: різнокольоровий, веселковий тощо.

Таблиця 2. Відповіді учнів 4 класів на запитання «Якого кольору добро?»

\begin{tabular}{|c|c|c|c|c|c|c|}
\hline \multirow{3}{*}{ Колір } & \multicolumn{6}{|c|}{$\begin{array}{l}\text { Кількісні дані за вибором кольорів у дітей, за мовою навчання } \\
\text { у школі і спілкування вдома }\end{array}$} \\
\hline & \multicolumn{2}{|c|}{$\begin{array}{l}\text { Український клас, } \\
\text { українська мова вдома }\end{array}$} & \multicolumn{2}{|c|}{$\begin{array}{c}\text { Російський клас, } \\
\text { російська мова вдома }\end{array}$} & \multicolumn{2}{|c|}{$\begin{array}{c}\text { Український клас, } \\
\text { російська мова вдома }\end{array}$} \\
\hline & $\begin{array}{l}\text { Кіл-сть } \\
\text { виборів }\end{array}$ & $\%$ & $\begin{array}{l}\text { Кіл-сть } \\
\text { виборів }\end{array}$ & $\%$ & $\begin{array}{l}\text { Кіл-сть } \\
\text { виборів }\end{array}$ & $\%$ \\
\hline Загальна кількість & 52 & 100 & 66 & 100 & 43 & 100 \\
\hline Теплі & 25 & 48 & 18 & 27,3 & 11 & 25,6 \\
\hline Холодні & 11 & 21,2 & 19 & 28,8 & 10 & 23,25 \\
\hline Зелений & 4 & 7,7 & 10 & 15,1 & 6 & 13,95 \\
\hline Білий & 5 & 9,6 & 15 & 22,7 & 9 & 20,9 \\
\hline Різний & 7 & 13,5 & 4 & 6,1 & 7 & 16,3 \\
\hline
\end{tabular}

Отримані результати опитування свідчать, що у всіх вибірках переважають теплі кольори. Добро асоціюється 3 теплом, допомогою, щирістю i таке інше. Як видно з даних поданих у табл. 2 в україномовних дітей виборів теплих кольорів 48\% майже у двічі більше ніж у російськомовних 27,3\% і змішаномовних 25,6\%. А нейтральних і білого (теж нейтрального) у двічі менше. На нашу думку, обидва факти пов'язані з можливістю ідентифікації себе зі своїм уявленням про добро.

Загальні уявлення, комплекси дитини, які збігаються 3 поняттями дорослих (Выготский, 1982), можуть стосуватися і конкретних, i абстрактних категорій, можуть бути цілісними недиференційованими (міфологізованими) i розміфологізованими в сенсі розділення змісту і форми. «Добро» як допомога, радість, щирість піддаються розділенню змісту і форми вже у молодшому шкільному віці.

Дитина може уподібнювати себе людям, які надають допомогу, приносять радість, є щирими. Асоціації, «добро - щастя», чи «добро - мама», позначаються теплими кольорами. А асоціації, у яких складно відділити зміст від форми, як «добро - зло», позначаються холодними, або нейтральними кольорами. 
Вибір білого кольору російськомовними дітьми 22,7\% і змішаномовними 19,1\%, більш, ніж удвічі переважає вибір білого україномовними учнями. Отримані дані, на нашу думку, свідчать про опозицію «добра i зла», «білого і чорного» - асоціації за контрастом, яка є основою «комплексу колекції» (Выготский, 1982).

Отримані результати розкривають ще одну проблему, яка виходить далеко за межі молодшого шкільного віку. Якщо асоціації за суміжністю чи схожістю (добро, допомога) спонукають до розділення змісту і форми, до мисленнєвих операцій порівняння, аналізу, аналогізування тощо, то асоціації за контрастом (добро, зло) розміфологізації не потребують. Асоціація Гітлер - Сталін, може бути асоціацією, як за схожістю, так і за контрастом. Асоціація за схожістю: Гітлер, Сталін - зло, спонукає до пошуку відповідей на питання чим вони схожі і чим відрізняються. Асоціація за контрастом Гітлер - зло, Сталін - добро такої спонукальної сили не має. Він «добро», лише тому, що бореться зі злом. Багато навіть дорослих людей уподібнюють боротьбу зі злом добру, створюючи міфи далекі від того, що є в дійсності.

Холодні i нейтральні кольори можна розглядати, як певне відсторонення через складність ідентифікації себе 3 недиференційованим чи навіть амбівалентними уявленнями добра, появу протилежних особистісних смислів. Вчинки, які учень вважав добрими, можуть виявитися поганими. Коли учень другого класу повідомляє учителю про поганий вчинок однокласника він робить, на його думку, добре, адже хоче, щоб однокласник також був хорошим. А у третьому, четвертому класі, через такі «добрі» вчинки з ним перестають дружити. Учні починають усвідомлювати відмінності норм і цінностей у різних групах, до яких вони належать - сім'я, клас, позашкільні групи. Вірогідно відбувається змішування особистісних смислів i, як результат, «змішування фарб» візуально чуттєвого відображення.

Слід зазначити, що у частини змішаномовних учнів опозиція «добро - зло» асоціюється 3 червоним кольором. Що на нашу думку пов'язано зі зміною енергетичної зарядженості асоціацій змішаномовних порівняно з одномовними.

Те що засвоєння російської мови порівняно 3 засвоєнням української сприяє формуванню більшої кількості асоціацій за контрастом, асоціацій з недиференційованими образами чітко видно 
у більшості слів представлених у «Слов’янському асоціативному словнику» особливо у конкретних уявленнях. Наприклад, російською - «Дружина: чоловік 129; мати 22; вірна 20...», українською - «Дружина: вірна 67; кохана 37 ; чоловік 17...» (Уфимцева, 2004: 112-113). У російському словнику асоціація за контрастом стоїть на першому місці, а в українському на третьому. Кількість виборів 129 проти 17. У російському словнику у першій десятці слів-асоціацій до слова «дружина» лише три прикметники, а в українському - 6 (Уфимцева, 2004: 112-113).

Суттєвими є вибори «добро - різнокольорове, веселкове і перерахування кольорів». До того ж, перерахування кольорів частіше зустрічається у змішаномовних, а у деяких із них зустрічаються такі кольори, як фіолетовий, коричневий і сірий. Слід зауважити, що у деяких студентів, нашого першого дослідження, фіолетовий, сірий і коричневий зустрічалися не у ряду кольорів, а самостійно, як то «Добро - сірого кольору». Тут мабуть можна констатувати, як позитивні фактори, коли інтеграція концептів обох мов може сприяти розвитку більш багатих уявлень, так і негативні моменти. «Добро» сірого, коричневого чи фіолетового кольору занадто бідне і малопривабливе.

Аналізуючи дані, подані у табл. 2, можна виділити ще одну закономірність - у російськомовних учнів виборів «добра», як різнокольорового (веселкового) у понад двічі менше $(6,1 \%)$, ніж в україномовних $(13,5 \%)$ і змішаномовних $(16,3 \%)$. На нашу думку, це пов'язане 3 тим, що сім'я слів «добра» в українській мові більша, ніж у російській. За даними російських дослідників у російській мові слово «добро» має асоціативні зв'язки з 29 словами, а в українській з - 36 (Уфимцева, 2004: 6-7). Чим більше асоціативних зв'язків, тим більша вірогідність формування різнокольорових образів. У зв'язку з цим у білінгвів показники повинні бути вищі, ніж у одномовних.

Результати нашої розвідки співвідносяться 3 низкою досліджень російських науковців, які розглядають «концепт добра», як протиставлення «добра» і «зла». Тобто асоціації «доброзло», «біле-чорне» залишаються домінуючими у свідомості і російських поетів, і російських науковців. Концепт «добра» через протиставлення «злу» було виявлено і у російськомовних студентів. Що $\epsilon$ закономірним, зважаючи на широке поширення такого 
концепту у російській літературі. Але у змішаномовних учнів четвертих класів протиставлення «добра» і «зла», на рівні уявлення, зустрічається значно частіше ніж у російськомовних, що породжує цілу низку нових запитань, та потребує нових досліджень.

Виявлені асоціації опозицій «добро - зло» 3 червоним кольором, на нашу думку, співвідноситься 3 теорією пасіонарності Л.С. Гумільова. Мова йде про зміну емоційної зарядженості образів, що формуються у змішаномовних дітей порівняно 3 одномовними. Навіть однакові слова, які мають однакове значення, можуть мати різне ставлення до них: різну емоційну інтенсивність і різний емоційний заряд. Так українське слово «дівка», яке російською звучить майже так само, і означає обома мовами незаміжню дівчину, українською мовою викликає додатні емоції, а російською від’ємні (Бедлінський, 2017: 29).

Суржик змінює мереживо асоціативних зв’язків і впливає на ï емоційну зарядженість. А окремі запозичення, на нашу думку, взагалі блокують збудження образів i, як результат, блокують потоки свідомості (Бедлінський, 2017: 30).

Змішаномовність як причина зміни емоційної зарядженості асоціативних зв'язків, що передаються у спадок у процесі опанування мовою, може претендувати на роль джерела збудження пасіонарної енергії етносу. Найслабшим місцем у теорії пасіонарності Л.М. Гумільова $є$ положення, що пасіонарність продукт генетичної мутації (Гумилёв, 2001). Мовленнєві «мутації» як змішування образів, емоційних зарядів і емоційного забарвлення асоціацій різних мов, які передаються у спадок, на нашу думку, підходять на роль причини пасіонарних збурень краще, ніж випадкові мутації Л.М. Гумільова.

Аналіз «Слов’янського асоціативного словника» дає підстави стверджувати, що у носіїв російської мови порівняно 3 носіями української, білоруської і болгарської мов асоціації за контрастом переважають над іншими. Коли наша гіпотеза підтверджується, то дані словника (Уфимцева, 2004) повинні бути дещо іншими. Автори не пишуть про білінгвізм, чи засміченість мови запозиченнями 3 російської, в українських і білоруських студентів. Разом із тим у зворотньому асоціативному словнику українською зустрічається велика кількість запозичень із російської: «бегать», «бред», «бумага», «бутилка», тощо (Уфимцева, 2004: 637-641), що на 
нашу думку свідчить про певну кількість білінгвів, чи людей, які зловживають суржиком, а отже, вплинуло на дані словника у бік збільшення асоціацій за контрастом у білоруських та українських студентів.

Той факт, що загальні уявлення залежать не лише від власного досвіду i опанування культурою, а i від опанування мовою співвідноситься 3 дослідженнями Альварез Дж.А. і Оліва А., які встановили, що цілісні представлення можуть бути досить точними навіть за умови неточності окремих складових. «У деяких випадках об’єкти, що знаходяться поза зоною уваги, настільки погано представлені, що здається ніби ми взагалі не маємо корисної інформації про них. Однак, виявилося можливим поєднання цієї неточної інформації для відновлення точного показника групи» (Alvarez, 2008; Alvarez, 2011: 123). Автори досліджуючи увагу у процесі обробку візуальної інформації виявили закономірності, які, на нашу думку, стосуються не лише уваги, образів сприймання i пам’яті, a, i образів уявлень, їх значень і смислів.

На нашу думку, у процесі опанування мовою засвоєння сімей слів, ідіом, приказок, прислів їв, граматичних, синтаксичних правил тощо (нарівні 3 опануванням культурою i накопиченням власного досвіду) формуються асоціації, які будучи мало усвідомленими чи взагалі неусвідомленими, впливають на формування змісту значень та особистісних смислів загальних уявлень.

\section{Висновки}

Підводячи підсумок проведеної емпіричної розвідки, можна стверджувати, що у процесі опанування рідною мовою, нарівні 3 опануванням культурою i накопиченням власного досвіду, формуються асоціації, які, будучи мало усвідомленими чи взагалі неусвідомленими впливають на формування змісту значень та особистісних смислів загальних уявлень, зокрема уявлення добра та зла.

На формування загальних уявлень впливає, як рідна мова, так і мова навчання. В учнів четвертих класів, у яких рідна мова відрізняється від мови навчання, уявлення «добра» як особистісних смислів можуть відрізнятися від уявлень учнів, які навчаються рідною мовою. У змішаномовних молодших школярів у порівнянні 
3 україномовними і російськомовними учнями у поясненні «добра» збільшується кількість визначень через опозицію «злу», що може загрожувати радикалізацією у майбутньому.

Мова, окрім усього іншого, є системою, яка може фіксувати, зберігати i передавати асоціації у спадок. Різномовність сприяє зміні асоціативних зв'язків уявлень та їх емоційного забарвлення i зарядженості порівняно 3 асоціаціями обох мов. Ці зміни можна розглядати як «спадково-мовленнєві мутації», що відкриває широкі перспективи для досліджень у світлі теорії пасіонарності Л.М. Гумільова.

Проведене дослідження не вичерпує всіх аспектів проблеми формування загальних уявлень молодших школярів в умовах білінгвізму, потребує подальших експериментальних досліджень та теоретичного осмислення. Перспективними видаються кроскультурні дослідження впливу білінгвізму та змішаномовності на функціонування свідомості у мовленні в різні вікові періоди.

\section{Література}

Бедлінський, О. Запозичена лексика чи світогляд свого народу? Украӥнська мова $i$ література в школі. 2017. № 1 (130). С. 27-31.

Бедлінський, О.I. Мовленнєва гіпотеза свідомості. Technologies of intellect development. 2017. T. 2. № 5 (16). URL : http://psytir.org.ua/upload/journals/2.5/ authors/2017/Bedlinskyj_Oleksij_Ivanovych_Movlennjeva_gipoteza_svidomosti. pdf

Величковский, Б.М. Когнитивная наука: Основы психологии познания : в 2 т. т. 2. Москва : Академия, 2006. 432 с.

Выготский, Л.С. Собрание сочинений: в 6-ти т. Т. 2. Проблемы общей психологии ; под ред. В.В. Давыдова. Москва : Педагогика, 1982. 504 с.

Гумилёв, Л.Н. Этногенез и биосфера Земли. Санкт-Петербург : Кристалл, 2001. 642 c.

Зинченко, В.П. Сознание и творческий акт. Москва : Языки славянских культур, 2010. 592 c.

Лурия, А.Р. Язык и сознание ; под редакцией Е.Д. Хомской. Москва : МГУ, 1979. $320 \mathrm{c}$.

Потебня, А.А. Полное собрание сочинений. Т. 1. Мысль и язык Киев : Государственное издательство Украины, 1926. 208 с. URL : http://elib. gnpbu.ru/text/potebnya_pss-t1_mysl-i-yazyk_1926/go,0;fs,1/

Уфимцева, Н.В., Черкасова, Г.А., Караулов, Ю.Н., Тарасов, Е.Ф. Славянский ассоциативный словарь: русский, белорусский, болгарский, украинский. Москва : АГУ, 2004. 800 с.

Фаликман, М.В., Коул, М. «Культурная революция» в когнитивной науке: от нейронной пластичности до генетических механизмов приобретения культурного опыта. Культурно историческая психология. 2014. Т. 10. № 3. C. 4-18. URL: https://psyjournals.ru/files/71857/kip_3_2014_falikman.pdf 
Alvarez, G.A., \& Oliva, A. (2008). The representation of simple ensemble visual features outside the focus of attention. Psychological Science, 19, 392-398. doi.org/10.1111/j.1467-9280.2008.02098.x

Alvarez, G.A. (2011). Representing multiple objects as an ensemble enhances visual cognition. Trends Cognitive Science, 15, 122-131. doi: 10.1016/j.tics.2011.01.003

Cohen Michael, A., Ken Nakayama, Konkle Talia, Stanti Mirta, \& Alvarez George, A. (2015). Visual Awareness Is Limited by the Representational Architecture of the Visual System. Journal of Cognitive Neuroscience, 27 (11). doi:10.1162/jocn_a 00855

Cohen Michael, A., Dennett Daniel, C., \& Kanwisher Nancy (2016). What is the Bandwidth of Perceptual Experience? Trends in Cognitive Sciences, 20 (5). Retrieved from: http://dx.doi.org/10.1016/j.tics.2016.03.006

Romanyuk, L., \& Schwarzer, R. (2018). Analysis of Indirect and Differential Connections Among Personal Values. Science and education, 1, 5-13. Odessa. doi.org/10.24195/2414-4665-2018-1-1

\section{References}

Alvarez, G.A., \& Oliva, A. (2008). The representation of simple ensemble visual features outside the focus of attention. Psychological Science, 19, 392-398. doi. org/10.1111/j.1467-9280.2008.02098.x

Alvarez, G.A. (2011). Representing multiple objects as an ensemble enhances visual cognition. Trends Cognitive Science, 15, 122-131. doi: 10.1016/j.tics.2011.01.003

Bedlinskyi, O. (2017). Zapozychena leksyka chy svitogliad svoho narodu? [Borrowed vocabulary or outlook of native people]. Ukrayinska mova i literatura $v$ shkoliUkrainian language and literature at school, 1 (130), 27-31 [in Ukrainian].

Bedlinskyj, O.I. (2017). Speech hypothesis of consciousness. Technologies of intellect development. Vol. 2, 5 (16). URL : http://psytir.org.ua/upload/journals/2.5/ authors/2017/Bedlinskyj_Oleksij_Ivanovych_Movlennjeva_gipoteza_svidomosti. pdf [in Ukrainian].

Cohen, Michael A., Ken, Nakayama, Konkle, Talia, Stanti, Mirta, \& Alvarez, George, A. (2015). Visual Awareness Is Limited by the Representational Architecture of the Visual System. Journal of Cognitive Neuroscience, 27 (11). doi:10.1162/jocn a 00855.

Cohen, Michael, A., Dennett, Daniel, C., \& Kanwisher, Nancy (2016). What is the Bandwidth of Perceptual Experience? Trends in Cognitive Sciences, 20 (5). URL : http://dx.doi.org/10.1016/j.tics.2016.03.006

Falikman, M.V., \& Cole, M. (2014). «Cultural Revolution» in Cognitive Science: From Neuroplasticity to Genetic Mechanisms of Acculturation. Cultural Historical Psychology, 10(3), 4-18. URL : https://psyjournals.ru/files/71857/kip_3_2014 falikman.pdf [in Russian].

Gumilev, L.N. (2001). Etnogenez $i$ biosfera Zemli [Ethnogenesis and the Earth's biosphere]. St. Petersburg : Kristall [in Russian].

Luriia, A.R. (1979). Iazyk $i$ soznanie [The language and consciousness]. Moscow : Izdatelstvo Moskovskogo universiteta [in Russian].

Potebnia, A.A. (1926). Polnoe sobranie sochinenij. Mysl i jazik [Complete collection of compositions. Thought and language]. Kyiv : Gosudarstvennoe izdatelstvo Ukrainy. URL : http://elib.gnpbu.ru/text/potebnya_pss-t1_mysl-i-yazyk_1926/ go, $0 ;$ fs, $1 /$ [in Russian]. 
Romanyuk, L., \& Schwarzer, R. (2018). Analysis of Indirect and Differential Connections Among Personal Values. Science and education, 1, 5-13. https://doi. org/10.24195/2414-4665-2018-1-1

Ufimtseva, N.V., Cherkasova, G.A., Karaulov, Iu.N., \& Tarasov, E.F. (2004). Slavianskii assotsiativnyi slovar: russkii, belorusskii, bolgarskii, ukrainskii [Slavic associative dictionary: russian, belarusian, bulgarian, ukrainian]. Moscow : Iz-vo AGU [in Russian].

Velichkovsky, B.M. (2006). Kognitivnaja nauka: Osnovy psihologii poznanija [Cognitive science: Foundations of epistemic psychology], (Vol. 2). Moscow : «Akademija» [in Russian].

Vygotskii, L.S. (1982). Sobranie sochinenii: Problemy obshchei psikhologii [Collected Works: Problems of general psychology], (Vols. 1-6, Vol. 2). Moscow : Pedagogika [in Russian].

Zinchenko, V.P. (2010). Soznanie $i$ tvorcheskii akt [Consciousness and creative act]. Moscow : Iazyki slavianskikh kultur [in Russian].

\section{АНОТАЦІЯ}

Суржик у мові сучасних молодших школярів, особливо у білінгвів поширене явище, зумовлене обставинами сучасного світу. У статmі розкриваються особливості загальних уявлень змішаномовних учнів, які навчаються у школі і спілкуються поза уроками різними мовами, що веде до вживання великої кількості запозиченої лексики з обох мов. 3 метою дослідження особливостей загальних уявлень в україномовних, російськомовних і змішаномовних школярів проводилося анкетування одномовних і двомовних учнів четвертих класів. Опитуванням охоплено 161 учня четвертих класів: 43 учні, які спілкуються у школі українською, а поза уроками російською; 55 учнів - переважно українською; 66 учнів переважно російською. у результаті дослідження були виявлені відмінності загальних уявлень та асоціацій уявлень з різними кольорами в учнів залежно від мови навчання i спілкування поза уроками. У процесі опанування рідною мовою, нарівні з опануванням культурою і накопиченням власного досвіду, формуються асоціації, які, будучи навіть мало усвідомленими чи взагалі неусвідомленими, впливають на формування образів уявлень і їх емоційне забарвлення. В учнів четвертих класів, у яких рідна мова відрізняється від мови навчання, уявлення "добра» можуть відрізнятися від уявлень учнів, які навчаються рідною мовою. у змішаномовних молодших школярів у порівнянні з україномовними i російськомовними учнями у поясненні "добра» збільшується кількість визначень через опозицію "злу», що може загрожувати радикалізацією у майбутньому. Мова, окрім усього іншого, $\epsilon$ системою яка може фріксувати, зберігати $і$ передавати асоціації у спадок. Різномовність сприяє зміні асоціативних зв'язків уявлень та їх емоційного забарвлення $і$ зарядженості порівняно з асоціаціями обох мов. Ці зміни можна розглядати як "спадково-мовленнєві мутації», що відкриває широкі перспективи для психолінгвістичних досліджень пасіонарності. 
Особливості уявлення добра одномовних та змішаномовних учнів..

Ключові слова: асочіація, білінгвізм, загальні уявлення, молодший школяр, пасіонарність, суржик.

\section{Бедлинский Алексей, Щербак Татьяна. Особенности представления добра одноязычных и смешаноязычных учащихся четвертых классов}

\section{АННОТАЦИЯ}

Суржик в языке современных младших школьников, особенно у билингвов распространенное явление, обусловленное обстоятельствами современного мира. В статье раскрываются особенности общих представлений смешаноязычных учащихся, обучающихся в школе и общающихся вне уроков на разных языках, что ведет к употреблению больщого количества заимствованной лексики в обоих языках. С целью исследования особенностей общих представлений в украиноязычных, русскоязычных и смешаноязычных школьников проводилось анкетирование одноязычных и двуязычных учащихся четвертых классов. Опросом охвачено 161 ученика четвертых классов: 43 ученика, которые общаются в школе на украинском, а вне уроков на русском; 55 учеников преимущественно на украинском; 66 учеников - преимущественно на русском. В результате исследования были выявлены различия общих представлений и ассоциирования представлений, с различными цветами у учащихся, в зависимости от языка обучения и общения вне уроков. В процессе освоения родного языка, наравне с овладением культурой и накоплением собственного опыта, формируются ассоциации, которые, будучи даже мало осознаваемым или вообще неосознанными, влияют на формирование образов представлений $и$ их эмоциональную окраску. В учащихся четвертых классов, у которых родной язык отличается от языка обучения, представление "добра» может отличаться от представлений учащихся, обучающихся на родном языке. У смешаноязычных младших школьников по сравнению с украиноязычными и русскоязычными учениками в объяснении "добра» увеличивается количество определений через оппозицию "злу», что может угрожать радикализацией в будущем. Язык, кроме всего прочего, является системой, которая может фиксировать, хранить и передавать ассоциации по наследству. Разноязычие способствует изменению ассоциативных связей представлений, их эмоциональной окраски и заряженности по сравнению с ассоциациями обоих языков. Эти изменения можно рассматривать как "наследственноязыковые мутации», что открывает широкие перспективы для психолингвистических исследований пассионарности.

Ключевые слова: ассоциация, билингвизм, общие представления, младший школьник, пассионарность, суржик. 